\title{
The Effects of Shifting Irrigation on Community Livelihoods and Environmental Quality in the Lower Ewaso Nyiro Basin of Isiolo County, Kenya
}

\author{
Nicodemus Nzombe and Nelson Mango* \\ Department of Environmental Studies and Community Development, Kenyatta University, Kenya
}

*Corresponding author: Nelson Mango, Department of Environmental Studies and Community Development, Kenyatta University, Kenya Submission: 監 April 02,2018; Published: 望 July 02, 2018

\begin{abstract}
This study sets out to investigate the effects of shifting irrigation on community livelihoods and environmental quality along the Ewaso Nyiro Basin of Isiolo County in Kenya. The study uses longitudinal data collected between 2006 and 2015 through participatory research techniques, case studies, observation, key informant interviews and questionnaire survey. Results from the study show that the lower Ewaso Nyiro basin has nine operational irrigation schemes which households along the basin depend to practice irrigation farming. Irrigation has diversified the means of livelihood of the people and is an important source of food in the lower Ewaso Nyiro basin. Due to irrigation practices, environmental degradation has been experienced. These include, soil erosion, deforestation, salinity and water logging. However biocide and chemical fertilizers use is low in these irrigation schemes. Environmental conservation practices are rarely practised in the irrigation schemes with minimal cases reporting soil erosion control, afforestation, soil fertility management and safe use of agro-chemicals. The study recommends portable means of lifting water from the river schemes and environmental conservation at the household level and at the scheme level in the short term. We also recommend policy measures that will ensure flood control at the catchment level as this will enable setting up of permanent irrigation schemes in the study area as a long term solution.
\end{abstract}

Keywords: Shifting irrigation; Livelihoods outcome; Land degradation; Environmental conservation; Kenya

\section{Study Background}

\section{Introduction}

Irrigation in the world dates back to $4000 \mathrm{BC}-3000 \mathrm{BC}$ in Mesopotamia and Egypt [1]. Kenya has a recorded history of about 400 years of irrigation development that was initially for food based traditional systems. Irrigation potential of Kenya has been estimated at 539,000 hectares. In 2003 there was 103,233 hectares of irrigation developed land with 20,000 hectares reclaimed through drainage [2]. By 2011 a total of 125,000 hectares had been put under irrigation of which smallholders represent $43 \%$, public at $18 \%$ while the private large scale farms represent $39 \%$ [3]. This was later expanded to 162,000 hectares by 2015 [4].

The role of irrigated agriculture in achieving food security at global level is well established [5]. According to Teshome [6], irrigation development has been promoted as a means of bringing about social-economic transformation since the Second World War. Government of Kenya [2,4] notes the importance of investing in irrigation agriculture as a means of improving agricultural productivity and reducing adverse weather impacts on production.
Understanding how irrigation fits into farmers' livelihoods is one of the lacunae in irrigation studies. Many studies in irrigation development focus on the production of irrigation system. Chambers [7] acknowledges that livelihood thinking has been applied minimally to irrigation. He, therefore, proposes that benefits from irrigation should be assessed in terms of its livelihood intensity-the number of households enabled by irrigation to gain adequate and secure livelihoods.

Farm Africa [8] notes that small-scale irrigation interventions can enable farmers to increase production. This can be done through intensification, by increasing to two or three harvests per year; improvement of nutrition and livelihoods through diversification and rising of income through commercialization. In Ethiopia smallscale irrigation has been used as a tool of encouraging pastoralists to adopt a sedentary lifestyle [8].

Although irrigation agriculture has a lot of benefits, it has some negative effects such as water logging, soil salinity due to evaporation of irrigation water, alkalinization of soils, social 
disruption due to relocation and settlement, erosion, siltation and encroachment into river catchments [9]. Loss of dry season grazing land and overgrazing are attributed to irrigation in pastoral areas by Ministry of Agriculture Livestock Development and Marketing [10]. Water use administration pose possible conflict between irrigation needs within the project and downstream activities [11].

According to Hogg [12], the Lower Ewaso Nyiro Basin in Isiolo County bore the brunt of the undeclared shifta war between Kenya and Somalia in the 1960s. Boran's herds and flocks were decimated largely due to government policy of human and livestock concentration. Camel population decreased by 95\%, small stock by $90 \%$ and cattle by $7 \%$. Between 1970 and 1979 cattle herds declined further by $40 \%$ due to drought. Government and donor communities responded to this massive destruction of livestock by distributing relief food and establishing small holder schemes to provide a new way of life. Irrigation schemes were thus introduced under the public sponsored small-scale Irrigation Project with funds from FAO and UNDP in the early 1970s. Other schemes were introduced in the area by church organizations, especially the Catholic Church. With changes of the river course, the major donor funded schemes collapsed. Malkadaka irrigation scheme collapsed in 1982, Merti irrigation scheme in 1987 and Garfasa irrigation scheme in 1998 .

Once the schemes are rendered defunct, the farming community shifts to new sites where they develop new schemes. This shifting irrigation involves using a piece of land only to abandon it when water becomes inaccessible. The length of farming in any given area is dependent on water availability. Since the schemes are developed along the riverbank, clearing of vegetation and breaking up the virgin ground goes with this irrigation system. This study therefore endeavored to assess the current status of this irrigation schemes and to evaluate their effect on community livelihoods and environmental quality.

\section{The study area}

The study area is in Isiolo County, which has $0.3 \%$ of arable land. The lower Ewaso Nyiro Basin stretches from Lorian swamp in Habaswein in Wajir County to the Chandlers Falls in Isiolo County. In Isiolo County it covers, Sericho, Merti and Garbatulla divisions.

The study area is in agro-ecological zone VII (very arid) according to Sombroek [13] classification. On average, during the long rains season (March-May), about $130 \mathrm{~mm}$ of rainfall is received which is less than half of the mean annual rainfall received in the area. During the short rains (October-December) about $145 \mathrm{~mm}$ of rainfall is received (ENNDA, 2002). High temperatures are experienced in the area with mean annual maximum and minimum at $33{ }^{\circ} \mathrm{C}$ and $20{ }^{\circ} \mathrm{C}$ respectively (ibid). This translates to a very high rate of evapotranspiration which was estimated by Sombroek [13] at $200 \mathrm{~mm}$ to $300 \mathrm{~mm}$ per month. With the high level of evapotranspiration and low rainfall, crop production in the study area is not possible without irrigation.

The Ewaso Nyiro River is the most important water source in the study area. It is perennial in its upper reaches with the point of zero flow varying between Sericho and Malka Bulfayo, depending on the rainfall further upstream; after Malka Bulfayo, the river often changes its course [14]. The Boran community is the dominant ethnic group in the study area. The Isiolo (waso) Boran is composed of two populations of different origins: the Boran (Guttu) who directly descended from Ethiopia and the Sakuye whose origin is less clear [14]. Poverty level among the pastoral communities is high as exemplified by external reliance on remittances, low household food security, low quality housing and, generally, poor supply of water and sanitation [15]. Isiolo County shows the lowest income of Kshs. 1356 per annum and has one of the highest infant mortality rates among the Countys of ENNDA region [15].

The government has made an effort to provide social infrastructures in the county though not adequate as this so far is only limited to paving the road that cuts across the County to Marsabit County and electricity supply to market centers. However the much needed essential commodity, water, is still a problem. A larger part of the County does not have passable roads and electricity. The poor means of communication has the capacity to affect foods transportation and input distribution as well as in the study area.

\section{Methodology}

The overall approach to the study is both qualitative and quantitative. Qualitative data was collected through Participatory Rural Appraisal techniques and extended case studies analysis for a period of about 9 years to track the changes that were taking place in the region. While quantitative data was collected through questionnaire survey in 2007. Purposive sampling was used to select the two schemes used in the study based on those schemes that were operational during the period of the study, their age and the instances of shifting. Kayo II and Korumtu irrigation schemes were sampled. 80 households were sampled from the two irrigation schemes by simple random sampling technique. From the eleven stakeholders organizations thirty representatives were sampled for questionnaire survey. The responses from the questionnaire survey were captured in modified four point Likert scale which was dichotomized into two. Four case studies were sampled purposively.

\section{Results and Discussion}

\section{The current status of irrigation schemes in the lower Ewaso Nyiro basin}

Table 1: Gender of the Respondents.

\begin{tabular}{|c|c|c|}
\hline \multirow{2}{*}{ Category of the Respondents } & \multicolumn{2}{|c|}{ Gender of Respondent } \\
\cline { 2 - 3 } & Male & Female \\
\hline Farmers & $79 \%$ & $21 \%$ \\
\hline Other Stakeholders (Professionals) & $96.70 \%$ & $3.30 \%$ \\
\hline
\end{tabular}

Most of the respondents were male headed households (Table 1). This is due to the fact that most of the households are headed by men. The professionals that formed part of the sample were also men given that few female staff are posted in the study area which is considered a hardship zone. 
Table 2: Gender of household and their educational levels.

\begin{tabular}{|c|c|c|c|c|}
\hline \multirow{2}{*}{} & \multicolumn{3}{|c|}{ Educational Level of Household Heads } \\
\cline { 2 - 5 } & None & Primary Level & Secondary Level & College Level \\
\hline Male & $79.30 \%$ & $13.80 \%$ & $5.20 \%$ & $1.70 \%$ \\
\hline Female & $90 \%$ & $0 \%$ & $10 \%$ & $0 \%$ \\
\hline Both Male and Female & $80 \%$ & $10 \%$ & $6.30 \%$ & $1.30 \%$ \\
\hline
\end{tabular}

The level of education of the household heads was generally low. $80 \%$ of the household respondents had not attained any formal education. $10 \%$ had attained primary education, $6.3 \%$ secondary education while $1.3 \%$ had attained college education (Table 2). Relatively high proportion of females (90\%) had not attained any educational level as compared to $79 \%$ of the men. Education levels largely determine entry into wage employment, hence determine income levels. Low education level indicates that few people move out of the study area to search for jobs elsewhere hence irrigation comes in handy as a source of employment.

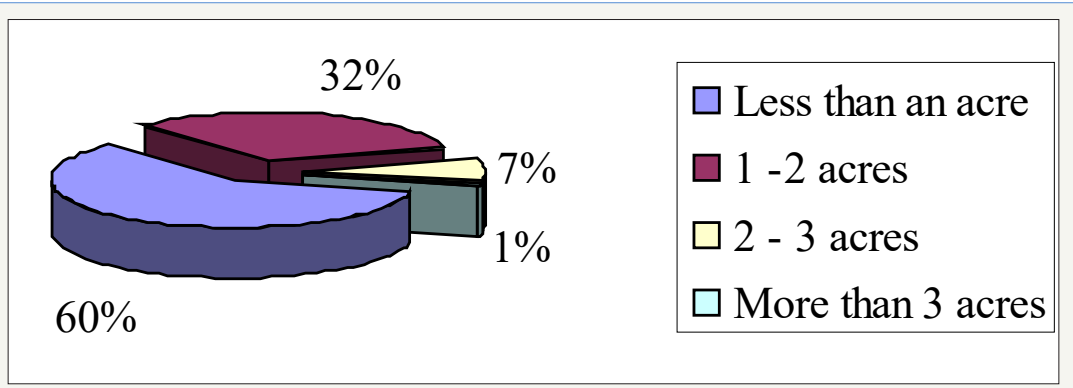

Figure 1: Household Farm Sizes.

Table 3: Functional Irrigation schemes in lower Ewaso Nyiro Basin in March 2013.

\begin{tabular}{|c|c|c|c|}
\hline Name of the Scheme & Division & Acreage of the Scheme (Hectares) & Number of Beneficiaries \\
\hline Koromtu & Merti & 5 & 97 \\
\hline Kayo II & Merti & 45 & 230 \\
\hline Arwasitu & Merti & 45 & 75 \\
\hline Korbesa & Merti & 15 & 70 \\
\hline Basa & Merti & 1.5 & 70 \\
\hline Biliqi & Merti & 10 & 34 \\
\hline Badan on Bora & Sericho & 15 & 97 \\
\hline Ires Kalicha & Sericho & 10 & 91 \\
\hline Hawaye & Sericho & 21 & 12 \\
\hline Malka Sericho & Sericho & 4 & \\
\hline
\end{tabular}

The minimum number of years of the respondents in crop production was one year while the maximum number of years was 32 with the average number of years being eight and mode of four years. More than $80 \%$ of the farmers had 10 years or less in crop production. Majority of the households (60\%) had farm holding of less than an acre, $32 \%$ reported acreage of 1 to 2 acres, $7 \%$ had 2 to 3 acres and only $1 \%$ had more than 3 acres (Figure 1). The functional irrigation schemes were Kayo II, Arwasitu, Dadachabasa, Korbesa and Malkagalla (Koromtu) in Merti division and Badan on Bora, Ires Kalicha, Hawaye, and Malka Sericho in Sericho Division. The current area under irrigation is 172 hectares with 791 beneficiaries (Table 3).

The number of irrigation schemes and the location of the irrigation schemes are highly dynamic. As compared to the annual report of the County Irrigation Office of 2006 there were irrigation schemes in Garbatulla division which had collapsed by the time of study while in Sericho division there were no irrigation schemes in 2006, by the time of the study in 2007 new irrigation scheme had been established.

The members of the schemes are normally heads of farm households. Irrigation scheme management structures (committees) exist in the study area, which are responsible for operation and maintenance of these schemes. The committees makes decisions and plays an important role in activities, such as maintenance of main and feeder canals, drainage repair, clearing and maintenance of farm roads, provision and arrangement of agricultural extension services, allocation of farm plots, canal protection, organizing fund raising (Harambee), dispute resolution, water allocation and mobilizing the farmers for communal work. 
The major causes of shifting irrigation are phenomenally associated with floods (Figure 2). Most of the household respondents $(93.8 \%)$ indicated that change of river course was important cause of shifting. Half of the household respondents (50\%) rated floods as important cause of shifting of irrigation scheme while change in river bed level was rated as an important cause of shifting of irrigation schemes by $51.3 \%$ of the household heads. Siltation was rated as important cause of shifting by $20 \%$ of the household head respondents.

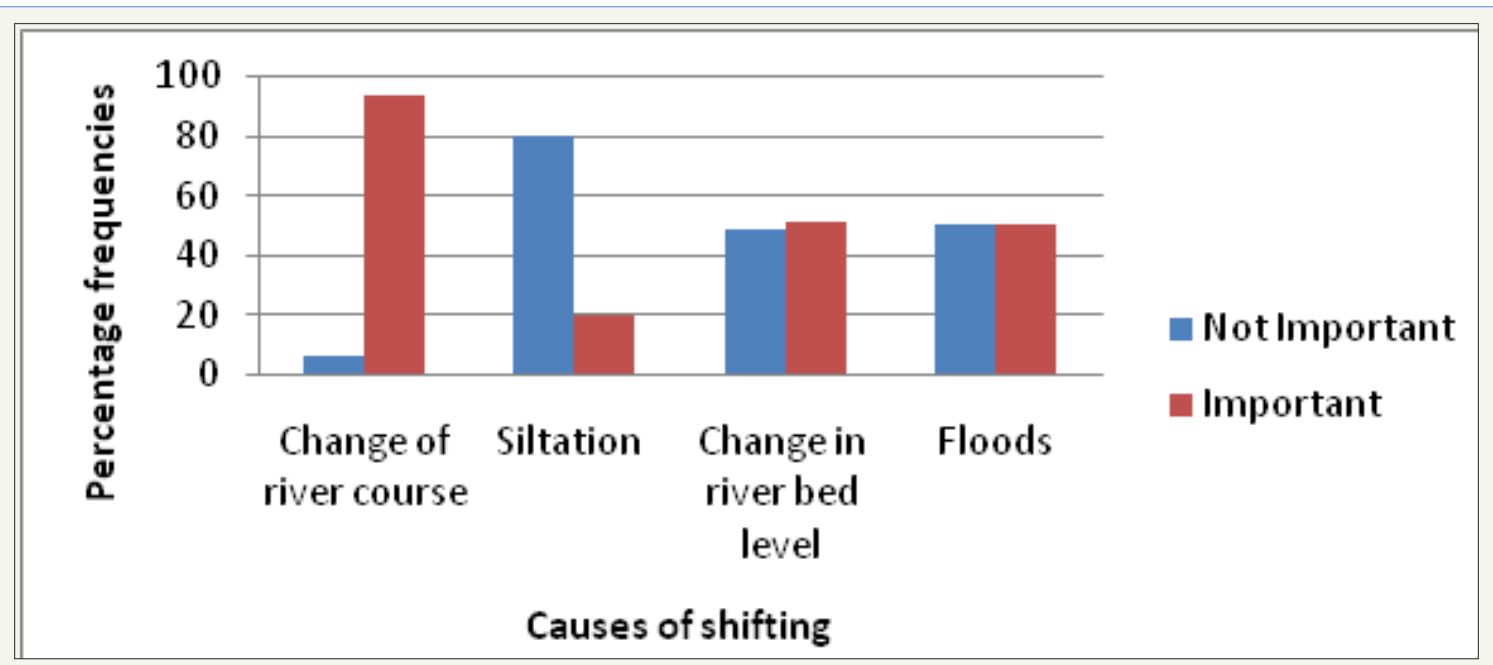

Figure 2: Causes of shifting of irrigation schemes.

Most of the respondents (97.5\%) reported that they shifted their scheme sites while $2.5 \%$ reported that they never shifted their scheme sites during their time in irrigation farming. The number of shifts by individual farmers ranged from 1 to 7 times. For Kayo II in Bulesa, historical timeline indicate that irrigation started in 1970 and up to 2013, the irrigation schemes sites had shifted 8 times with some years without irrigation (Table 4). Duration of operation of the schemes in a single site ranged from one year to nine years in Bulesa. There was a positive correlation between the number of years in crop production and the number of times a scheme shifted its sites ( $r=0.456)$ at 0.001 significant level. Therefore farmers with more years in crop production have shifted their irrigation schemes site more than those who have few years in crop production. The high rate of shifting is a discouragement to long term investment in permanent irrigation structures.

Table 4:Historical Timeline for Bulesa.

\begin{tabular}{|c|c|}
\hline Year & Event \\
\hline 1969 & Settlement started in Bulesa \\
\hline 1970 & $\begin{array}{c}\text { Crop production was initiated by the local community. The Catholic Church moved in to assist in canal excavation under Father Pius. } \\
\text { The first scheme was called Wachu }\end{array}$ \\
\hline 1973 & Wachu collapsed due to salinity problems and low production. Hawaye 1 was started \\
\hline 1974 & Hawaye 1 collapsed due to change in water level. Some farmers went to Garfasa irrigation Scheme \\
\hline 1977 & Hawaye 2 started as the river changed its course. Farmers returned from Garfasa with the start of Hawaye 2 \\
\hline 1984 & Hawaye 2 collapsed due to change of water level in the river. No farming some farmers migrated to Garfasa \\
\hline 1989 & Badana irrigation scheme was started and farmers returned from Garfasa \\
\hline 1997 & Badana collapsed due to the Elnino floods which changed the river course and Umoja irrigation scheme started \\
\hline 2001 & Umoja 1 collapsed due to change in water level in the river and Kayo 1 irrigation scheme started. \\
\hline 2003 & Kayo 1 collapsed due to floods and Kayo 11 started. \\
\hline 2006 & Some farmers went back to former site of Nagele irrigation scheme leaving others in Kayo II. \\
\hline 2016 & The Kenya Government proposes to establish a Kshs 5 million in Bulesa sub-county \\
\hline
\end{tabular}


The irrigation structures used in the shifting irrigation schemes are temporal in nature. The conveyance structures are made up of unlined earth canal. The irrigation schemes do not have water regulating structure in their intake sites. The operating schemes do not have weirs across the river to raise the water level in the river. Therefore, when floods erode the river bed the irrigators cannot access water for irrigation. The schemes do not have water division structures, instead the farmers break the main canal to make the feeder canals and control the flow of water by scooping mud and soil to block the flow of water to the undesired sites.

The irrigation methods used in the lower Ewaso Nyiro are surface irrigation methods. There was a very highly significant association between irrigation methods and the level of importance attached to them by the farmers $\left(X^{2}=44.571 ; d f=3 ; p<0.001\right)$. This means the preference of irrigation methods differ from one farmer to another. Less than half of the household head respondents $(48.7 \%)$ indicated that basin irrigation method was important $51.7 \%$ of the respondents rated wild flooding as an important irrigation methods to them (Figure 3). Furrow irrigation is also practiced with $38.8 \%$ of the respondents ranking it as important. Furrow irrigation is used during the production of onions, kales, and spinach. Only $6.3 \%$ of the respondents rated bucket irrigation as important. Bucket irrigation is used in nursery management. Isaya [16] noted that although surface irrigation can be efficient (70\% or more) in a typical farmer's situation less than half of the applied water reaches the plant because of poor irrigation practices.

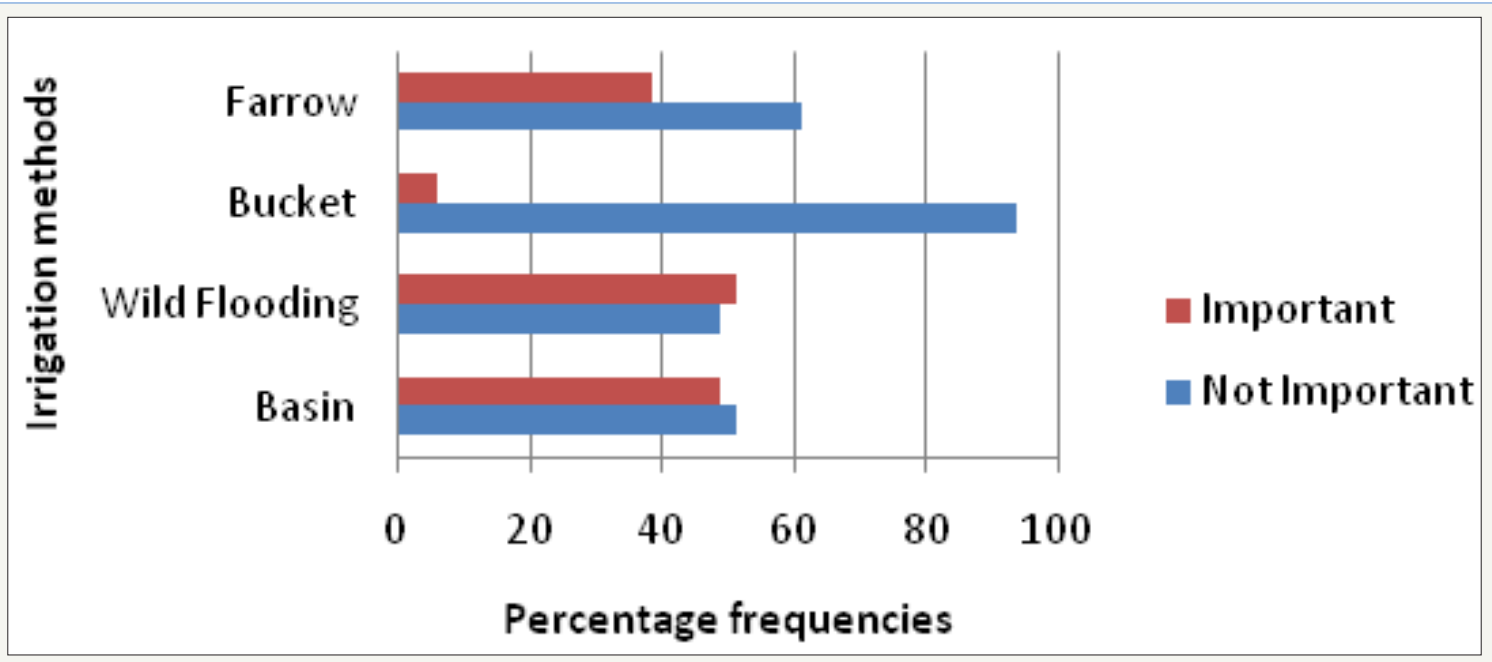

Figure 3: Relative importance of irrigation methods used.

\section{Effects of shifting irrigation schemes on community livelihoods}

During focus group discussion it was established that before introduction of irrigation means of livelihoods in the study area were livestock production (pastoralism), trade in livestock and livestock products and hunting and gathering among some specific clans. Irrigation has diversified livelihoods in the lower Ewaso Nyiro from purely livestock related livelihoods to crop based livelihoods. All the household heads interviewed rated crop production as important means of livelihood to them (Figure 4). Other means of livelihoods have emerged due to irrigation, 35\% of the household heads indicated that trade in agricultural produce was an important means of livelihood to them while $3.8 \%$ indicated that agricultural casual labor was an important means of livelihood to them.

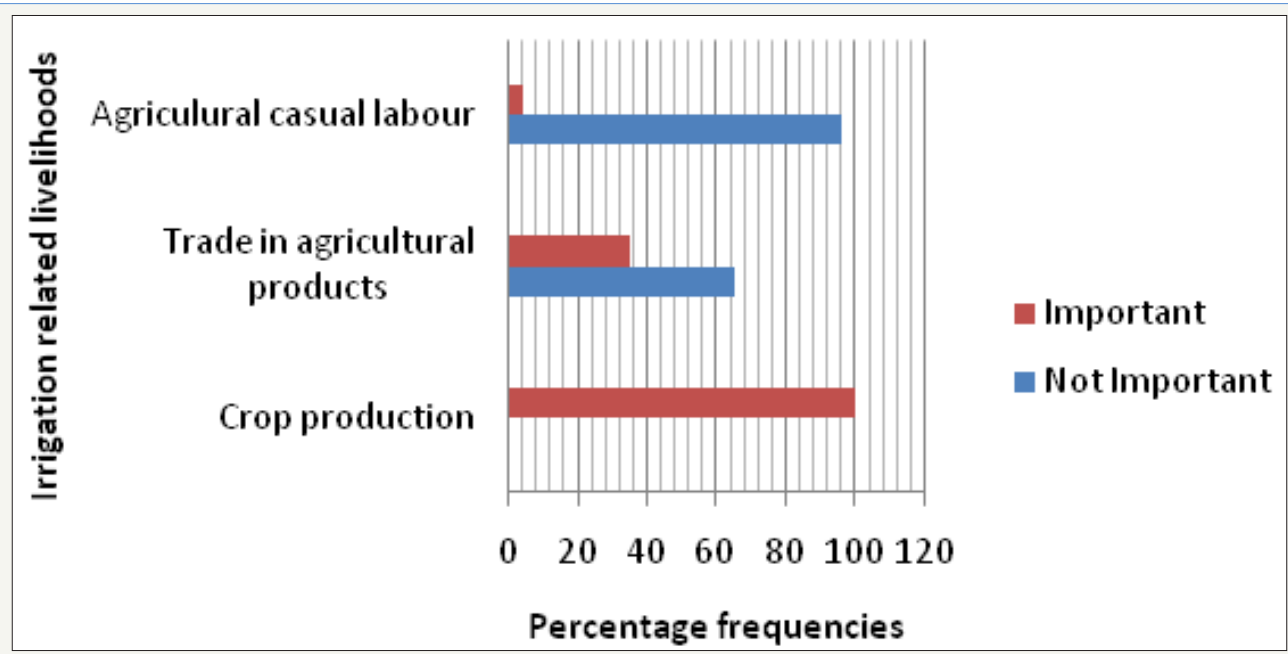

Figure 4: Emerging livelihoods due to irrigation. 
Irrigation has assisted farmer without livestock to diversify in livestock production. This can be illustrated by case study 1 below.

Case study 1: Case study 1 is a 74 year old farmer in Kombolla. He started farming in 1973 while in Somalia. He returned to Kenya in 1997 from Somalia and had no livestock. He was allocated 10 basins in block 17 of Garfasa irrigation scheme of which he planted tomatoes, pumpkins and maize. The maize was used for home consumption. He sold the tomatoes and pumpkins and bought eight goats. He moved to Kombolla where they started an irrigation scheme and continued irrigation farming. With the proceeds, he bought two cows and added ten goats. The cows had multiplied up to twelve but they perished due to 2006 drought leaving him with only two cows, two calves and seven goats. In 2016 with the proceeds from the irrigation scheme he had started a farm input store that was being managed by his son as he was now very old. His Gut Kombollo aged 40 praises his father's efforts in the scheme as it is there that they harvested their fortune. His younger brother Diro Kombollo managed to buy a motorcycle which he uses to ferry people to Isiolo town. He bought this bicycle with the proceeds from the scheme in 2014. Irrigation farming has also enabled some farmers to diversify into other income generating ventures. This is illustrated by case 2 below.

Case study 2: Case study 2 is a 69 year old farmer in Garfasa location. Before he started farming he had lost his flock of 100 camels and two hundred goats due to drought. He started irrigation farming 27 years ago in the collapsed Garfasa irrigation scheme. From the proceeds of the first harvest, he purchased three donkey carts. He later purchased two more donkey carts. He uses the donkey carts to ferry people's property for pay. His son Lokitan Garfasa has remained in the scheme to date. He concentrates mainly on horticultural production. He states that "Not only has there not been enough rain in the past few years, it's also been unevenly distributed," he said, picking through the earth in his hand. "This destroys our crops. Dealing with more unpredictable and irregular rainfall associated with climate change is a challenge for us smallholder farmers". He is hopeful that the government will one day come to their assistance.

Irrigation has enhanced food security in the lower Ewaso Nyiro. Majority of the household heads $(88.7 \%)$ indicated that shifting irrigation was an important source of food. All the stakeholder respondents interviewed reported that irrigation is an important means of enhancing food security in the lower Ewaso Nyiro basin (Table 5). There was no significant association between the respondent type and the level of importance of irrigation as source of food $\left(X^{2}=3.676 ; d f=1 ; p=0.055\right)$.

Table 5: Relative importance of irrigation as source of food.

\begin{tabular}{|c|c|c|}
\hline \multirow{2}{*}{ Level of Importance } & $\begin{array}{c}\text { Household } \\
\text { Heads }\end{array}$ & Other Stakeholders \\
\cline { 2 - 3 } & Percentage & Percentage \\
\hline Not Important & 11.3 & \\
\hline Important & 88.7 & 100 \\
\hline
\end{tabular}

Irrigation has made food available for at least three months to six months for majority of irrigating household from their own farm. Of the household heads interviewed, 5\%, 72.5\%, 10\% and $12.5 \%$ reported that they used their own harvested food for less than three months, three to six months, six to nine months and nine months to a year respectively (Figure 5). Food availability for pure pastoral communities surrounding the irrigation schemes in the lower Ewaso Nyiro basin is enhanced though trade.

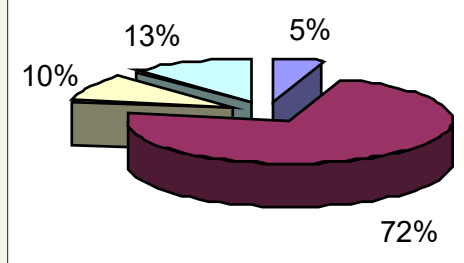

$\square$ Less than three months
$\square$ Three to six months
$\square$ Six to nine months
$\square$ Nine months to a year

Figure 5: Months using harvested food

Irrigation is a source of income to the farming community. Nearly a half (48.8\%) of the household heads interviewed indicated that they sold their farm produce (Table 6). In most cases, the farmers sell the excess produce.

Table 6: Proportion of respondents who sell farm produce.

\begin{tabular}{|c|c|}
\hline & Percent \\
\hline Sell farm produce & 48.8 \\
\hline Do not sell farm produce & 51.3 \\
\hline Total & 100 \\
\hline
\end{tabular}

\section{Effect of shifting irrigation to the environmental quality}

Bo Tengnas [17] noted that local people have a lot of knowledge about their own problems and potentials. Using this principle, this study endeavored to get information on how irrigation was impacting on the environment. When farmers identify the signs of environmental degradation, they are able to take part in coming up with solutions for the negative effects.

Gullies were identified as an important sign of environmental degradation due to irrigation in the lower Ewaso Nyiro basin. There was no significant association between the respondent type and the level of importance associated with gullies as a sign of 
environmental degradation $\left(\mathrm{X}^{2}=1.407 ; \mathrm{df}=1 ; \mathrm{p}=0.236\right)$. Most of the household respondents (91.3\%) and other stakeholders (83.3\%) indicated that gullies were important sign of environmental degradation in their irrigation schemes (Table 7). Along the banks of the main canal of Kayo II irrigation scheme gullies were visible features during the time of the study.

Table 7: Evidence of Environmental Degradation Due to Irrigation.

\begin{tabular}{|c|c|c|c|c|c|}
\hline \multirow{2}{*}{$\begin{array}{l}\text { Type of identified envi- } \\
\text { ronmental degradation }\end{array}$} & \multicolumn{2}{|c|}{$\begin{array}{l}\text { Percentage frequency of identified environmen- } \\
\text { tal degradation by farmers }\end{array}$} & \multicolumn{2}{|c|}{$\begin{array}{l}\text { Percentage frequency of identified environ- } \\
\text { mental degradation by other stakeholders }\end{array}$} & \multirow[t]{2}{*}{$\begin{array}{l}\text { Chi square } \\
\text { value }\end{array}$} \\
\hline & Important & Not Important & Important & Not Important & \\
\hline Gully erosion & $91.30 \%$ & $8.70 \%$ & $83.30 \%$ & $16.70 \%$ & $\begin{array}{c}\mathrm{X}^{2}=1.407 ; \mathrm{df}=1 \\
\mathrm{p}=0.236\end{array}$ \\
\hline Salinization & $32.20 \%$ & $68.80 \%$ & $46.70 \%$ & $53.30 \%$ & $\begin{array}{l}X^{2}=4.551 ; d f=1 \\
\quad p=0.033\end{array}$ \\
\hline Water logging & $20 \%$ & $80 \%$ & $46.70 \%$ & $53.30 \%$ & $\begin{array}{c}X^{2}=11.752 ; d f=1 ; \\
p=0.001\end{array}$ \\
\hline Deforestation & $72.50 \%$ & $27.50 \%$ & $86.70 \%$ & $13.30 \%$ & $\begin{array}{c}\mathrm{X}^{2}=2.246 ; \mathrm{df}=1 \\
\mathrm{p}=0.119\end{array}$ \\
\hline Reduction in yield & $63.80 \%$ & $36.20 \%$ & $73.30 \%$ & $26.70 \%$ & $\begin{array}{c}X^{2}=0.898 ; d f=1 \\
p=0.343\end{array}$ \\
\hline
\end{tabular}

CGIAR [18] referred to salinisation as increase in concentration of total dissolved solids in soil and water. Ministry of Agriculture and Livestock Development noted that as moisture evaporates, salts which have been dissolved in the water accumulate and salt efflorescence and crust forms. The visual characteristics are white salt crystal, a white salt crust covering the ground or very loose fluffy surface. There was a significant association between the respondent type and the level of importance associated with salinisation $\left(X^{2}=4.551 ; \mathrm{df}=1 ; \mathrm{p}=0.033\right)$ at the $5 \%$ significance level. Less than half $(32.2 \%)$ of the household respondents and other stakeholder (46.7\%) indicated that presence of salt residues was an important sign of land degradation in their shambas or their schemes.

Being earthen, the irrigation canals in the lower Ewaso Nyiro will always lose water. This can lead to problem of water logging. According to CGAIR [18], water logging refers to saturation of soils with water resulting from over-irrigation, seepage or inadequate drainage. There was a significant association between the respondent type and the level of importance attached to water logging as an evidence to environmental degradation in the study area $\left(X^{2}=11.752 \mathrm{df}=1 ; \mathrm{p}=0.001\right)$. Only $20 \%$ of the household heads and $46.7 \%$ of the other stakeholders identified presence of stagnant water as an important sign of environmental degradation in the irrigation schemes $[19,20]$.

Majority of the household respondents $(72.5 \%)$ indicated that deforestation was an important sign of environmental degradation in the irrigation schemes. This was supported by $86.3 \%$ of the other stakeholders. There was no significant association between the respondent type and the level of importance attached to deforestation $\left(X^{2}=2.739 ; \mathrm{df}=3 ; \mathrm{p}=0.434\right)$.

Majority of household heads respondents (63.8\%) rated reduction in yield as an important sign of environmental degradation due to irrigation this was supported by $73.3 \%$ of the other stakeholders. There was no significant difference between the responses of the two categories of respondents $\left(\mathrm{X}^{2}=0.898\right.$; $\mathrm{df}=1 ; \mathrm{p}=0.343$ ). Low yield in the study area can be attributed to many factors which include lack of the right farming inputs, poor agronomic practices among others. Therefore; it cannot be attributed fully to environmental degradation.

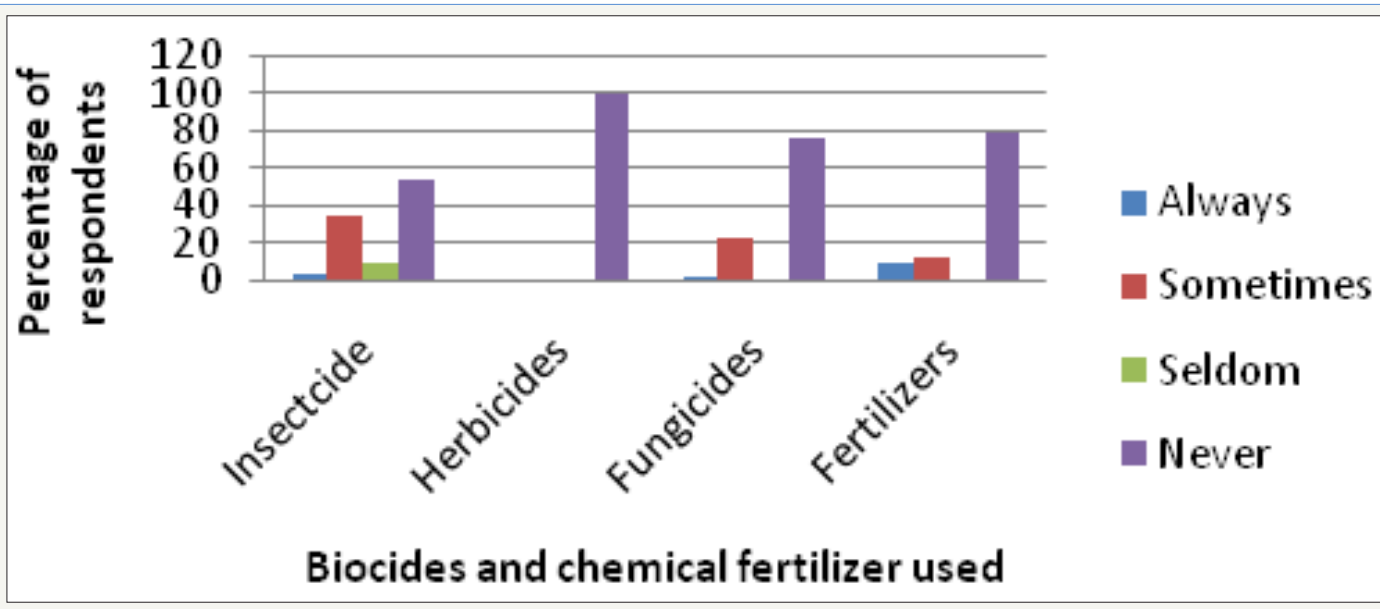

Figure 6: Frequency of use of biocides and fertilizers. 
Misuse of various biocides likeinsecticides, herbicides, pesticides and fungicides in irrigation schemes poses a health hazard to the farmer and the end user of the produce. Biocides have the potential for contaminating the ground water and the underground water if not managed with care. Most of the household head respondents reported low frequency of use of biocides and chemical fertilizers. There was a very highly significant association between the type of biocide/fertilizers use and the frequency of usage $\left(X^{2}=74.007\right.$; $\mathrm{df}=9 ; \mathrm{p}<0.001$ ). This is an indication that the frequency of use of biocide depends on the type of biocide/fertilizers. The highest frequency of biocides use was reported on insecticides with $46 \%$ of the household heads reporting some usage (Figure 6). All the household heads interviewed indicated that they had never used herbicides. Low proportion of the respondents (24\%) reported some use of fungicides. Majority of the respondents indicated they had never used chemical fertilizers with $21 \%$ reporting some use.
In the lower Ewaso Nyiro basin environmental conservation is practiced by few households. The main environmental conservation strategies practiced in the study area are agro-forestry, soil fertility management by use of boma manure (farm yard), soil erosion control and safe use of agro-chemicals. The conservation methods used are very highly significantly associated with their level of importance $\left(X^{2}=50.889 ; d f=9 ; p<0.001\right)$. Only 29\% of the household respondents reported practicing agro-forestry while $56 \%$ of the household respondents indicated some use of boma manure and (48\%) of household heads considered soil erosion control as an important environmental conservation methods they practiced (Figure 7). Few household heads (22.5\%) reported that safe use of agro-chemicals was an important environmental conservation practice to them. The low level of practice of safe use of agrochemical principles means the risks of agro chemical hazards are high. The low environmental conservation level can be attributed to lack of resource and technical knowledge.

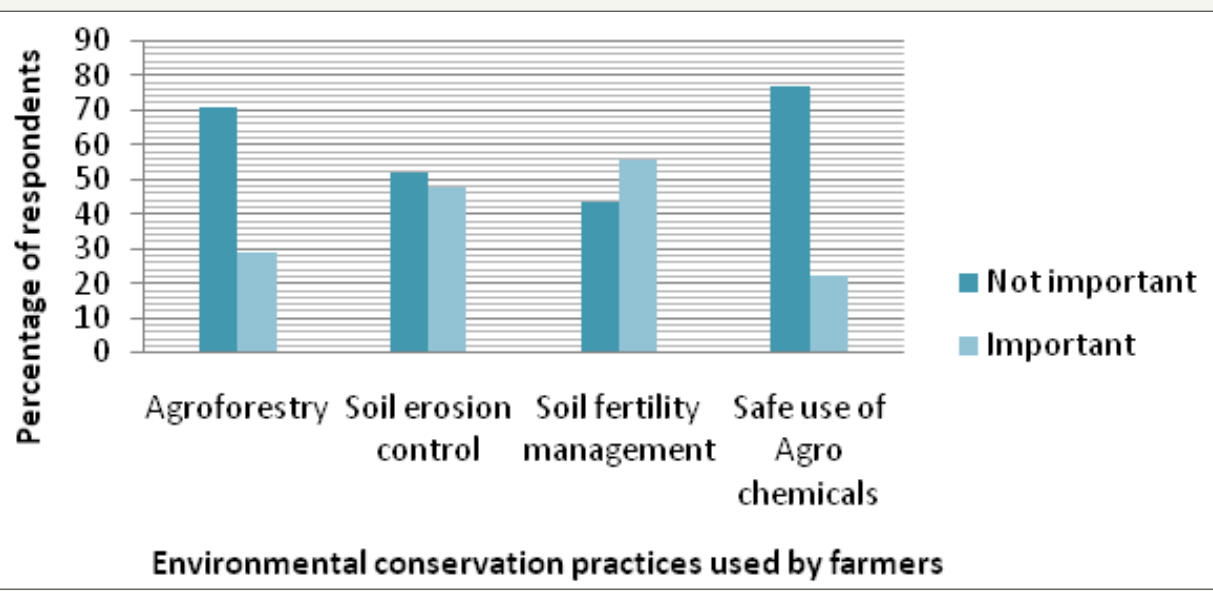

Figure 7: Environmental conservation practices used in by farmers.

\section{Conclusion and Recommendations}

In conclusion the study found that the lower Ewaso Nyiro has nine operational irrigation schemes and over 1000 households are practising irrigation farming. The schemes have a management unit, but are not formally recognised. The irrigation schemes do not have permanent structures and use surface irrigation methods which are inefficient. The major causes of shifting irrigation are phenomenon associated with floods. The irrigation schemes are highly dynamic and therefore investment in permanent structure is not advisable.

Irrigation has diversified the means of livelihood of the people with crop production being recognised as an important means of livelihoods. Some other means of livelihoods related to crop production have started to emerge. Irrigation has led to diversification in livestock production for those without livestock and irrigation has also assisted some farmers to come up with income generation activities. The shifting irrigation schemes have enhanced food security in the lower Ewaso Nyiro basin although not all year round. Despite the diversification of livelihoods and enhancement of food security, the livelihoods are not secure due to the constant shifting of the irrigation schemes and the food security cannot be relied on.

Irrigation has led to cases of environmental degradation in the study area. The major types of environmental degradation noted due to irrigation are soil erosion, deforestation, salinity and water logging. Low crop production was noted in the irrigation schemes despite which the usage of production enhancing technologies like biocide and chemical fertilizers is low in these irrigation schemes. Although the respondents could identify degradation in the area environmental conservation practices are rarely practised

To minimise the shifting of irrigation scheme sites this study recommends flood control measure to be put in place at the catchment level. In the short term, the study recommends portable means of lifting water from the river. A feasibility of a permanent irrigation scheme should be evaluated above Malka Bulfayo so as to give the farming community a more reliable means of livelihood. To improve on the yield and to enhance food security, this study recommends intensification of production by use of output enhancing techniques like use of certified seeds and practising of the right agronomic practises. 


\section{Acknowledgement}

The authors would like to acknowledge the support they received from the County Office in Malkagalla and Bulesa Locations, members of staff from the Ministry of Agriculture Merti and Garbatulla divisions, the Country Agricultural Officer in Isiolo, Ewaso Nyiro North Development Authority and the Arid Land Resource Management Project Isiolo and to all the farmers that participated in this research project.

\section{References}

1. Arnon DI (1972) Crop Production in Arid Regions. Hill, London, UK, England.

2. GOK (2005) Strategic Plan 2005- 2009. Ministry of Agriculture, Nairobi, Kenya.

3. Karina FZ, Mwaniki AW (2011) Irrigation Agriculture in Kenya: Impact of the Economic Stimulus Programme and Long-term Prospects for Food Security in an Era of Climate Change. Technical report, published by Think Interactive Limited, Nairobi, Kenya.

4. GOK (2015) Lower Ewaso Nyiro River basin Integrated and Multipurpose project. Technical Report. Ministry of Water and Irrigation, Nairobi, Kenya.

5. FAO, World Bank (2001) Farming Systems and Poverty. Improving Farmers Livelihoods in a Changing World. FAO, Italy.

6. Teshome W (2003) Irrigation practices, state of intervention and farmers life-word in drought prone tigray. PHD thesis. Wageningen University, Ethiopia.

7. Chambers R (1994) Irrigation against Rural Poverty in Social Economic Dimensions. In: Gurjar RK (Ed.), Print well, Jaipur, India.

8. Farm Africa (2006) Planning for Small-scale Irrigation Intervention Working Paper Series No.4. Farm Africa Ethiopia: Farm Africa, London, UK, England.

9. GOK (1999) Sessional Paper on Water Resource Management and Development. Ministry of Water. Nairobi, Kenya.
10.GOK (1993) Ministry of Agriculture, Livestock Development and Marketing, Guidelines on Smallholder Irrigation Projects for Implementing Agencies and Donors. Livestock and Marketing, Ministry of Agriculture, Nairobi, Kenya.

11. Worthington EB (1977) Arid Land Irrigation in Developing Countries. In: Barton Worthington E (Ed.), Environmental Problems and Effects. Pergamon Press, England.

12. Hogg R (1985) Restocking Pastoralists in Kenya. A Strategy for Relief and Rehabilitation. Paper 19C, Pastoral Development Network, London, UK, England.

13. Sombroek WG, Vleeshouwer JJ, Wokabi (1973) Report of Site Evaluation of Irrigation Suitability of the Soils and Waters of Merti Area (Isiolo County). Kenya Soil Survey Report No. P7.

14. (1993) Ministry of Agriculture, Livestock Development and Marketing Range, Management Hand Book of Kenya Volume II, 5. Isiolo County Ministry of Agriculture, Livestock Development and Marketing, Range Management Division, Nairobi, Kenya.

15. ENNDA (2002) Ewaso Nyiro North River Catchment Conservation and Water Resource Management Study Main Report. ENNDA Nairobi, Kenya.

16. Isaya VS (2001) Drip Irrigation Option for Small Holder Farmers Eastern and Southern Africa. Technical Hand Book No.24 Regional Land Management Unit.

17. Bo Tengnas (1993) Guidelines on Agro Forestry Extension Planning in Kenya. Regional Soil Conservation Unit Swedish International Development Authority, Nairobi, Kenya.

18. CGIAR (2001) Consultative Group on International Agricultural Research (CGIAR) Environmental Impact of Productivity Enhancing Crop Research: Critical Review.

19. Sombroek WG, Braun HMH, Van Der Pouw BJA (1982) The Exploratory Soil Map and Agro Climatic Zone Map of Kenya 1980. AGRIS 56.

20. Agricultural Information Resource Centre (AIRC), Irrigation Development for Food Security, Wealth and Employment (2006) Proceedings of the National Irrigation Stakeholders Workshop, AIRC, Nairobi, Kenya.
Creative Commons Attribution 4.0 International License

For possible submissions Click Here

\section{Submit Article}

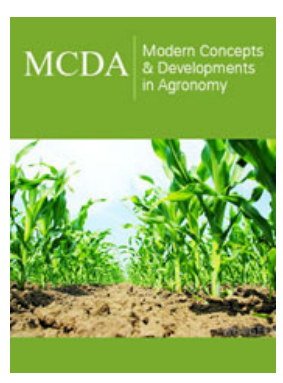

Modern Concepts \& Developments in Agronomy

Benefits of Publishing with us

- High-level peer review and editorial services

- Freely accessible online immediately upon publication

- Authors retain the copyright to their work

- Licensing it under a Creative Commons license

- Visibility through different online platforms 